\title{
Parálisis facial periférica en una pintura de Goya: el retrato de D. Andrés del Peral
}

\section{Peripheral facial palsy in a painting by Goya: D. Andrés del Peral's portrait}

\section{Sr. Director:}

En la sala 39 de la National Gallery de Londres, entre el retrato de la bellísima Dña. Isabel de Porcel -vestida de maja-, y del altivo Duque de Wellington — cargado de condecoraciones-, nos observa, con el rostro algo sombrío, D. Andrés del Peral. Todos ellos retratados por Goya y, con razón, parte de los más apreciados tesoros de la galería. D. Andrés, a la sazón de 48 años, sentado de medio cuerpo con casaca gris plata, esconde su mano derecha en el chaleco, y nos mira fijamente. Pero llama inmediatamente la atención en su facies un "gesto extraño", en expresión de una afamada web de arte ${ }^{1}$. Efectivamente, en el rostro se observa una asimetría facial, con caída de la parte izquierda de las comisuras labiales (Fig. 1). Dada la minuciosidad cuasi-fotográfica de Goya parece imponerse un diáfano diagnóstico: parálisis facial periférica (parálisis de Bell). Y así lo reconoce el propio rótulo acompañante de la galería: "The drop on the left side of Peral's face may have been the result of an illness such a palsy"2.
Andrés del Peral trabajó en el Palacio Real y Reales Sitios entre 1774-1778 como pintor dorador y se dedicó también a la decoración de coches de caballos. Poseyó una importante colección de pintura, incluidas varias de Goya, que vendió en 1808 a Carlos IV. Fue también agente en Francia de intereses de la Corte española. Goya realizó su retrato en 1798, exponiéndolo en la Academia de San Fernando. La nieta del retratado lo vendió al marqués de la Vega-Inclán, pasó luego a la colección Gastón Linden (París) y en 1904 sir George Donaldson lo donó a la National Gallery ${ }^{3-5}$.

Dicho retrato debe ser uno de los primeros conocidos en mostrar la parálisis facial, incluso anticipándose a su más conocida descripción, pues aunque se encuentra ya en textos de Hipócrates, arábes o de Sydenham, ha permanecido el epónimo de su caracterización en el siglo XIX por Charles Bell (1774-1842). Por mucho tiempo denominada idiopática, hoy se considera en la mayoría de casos debida a infección vírica, especialmente virus herpes tipo 1 y varicela-zóster. Su pronóstico en cuanto a recuperación completa es del $70 \%$ y

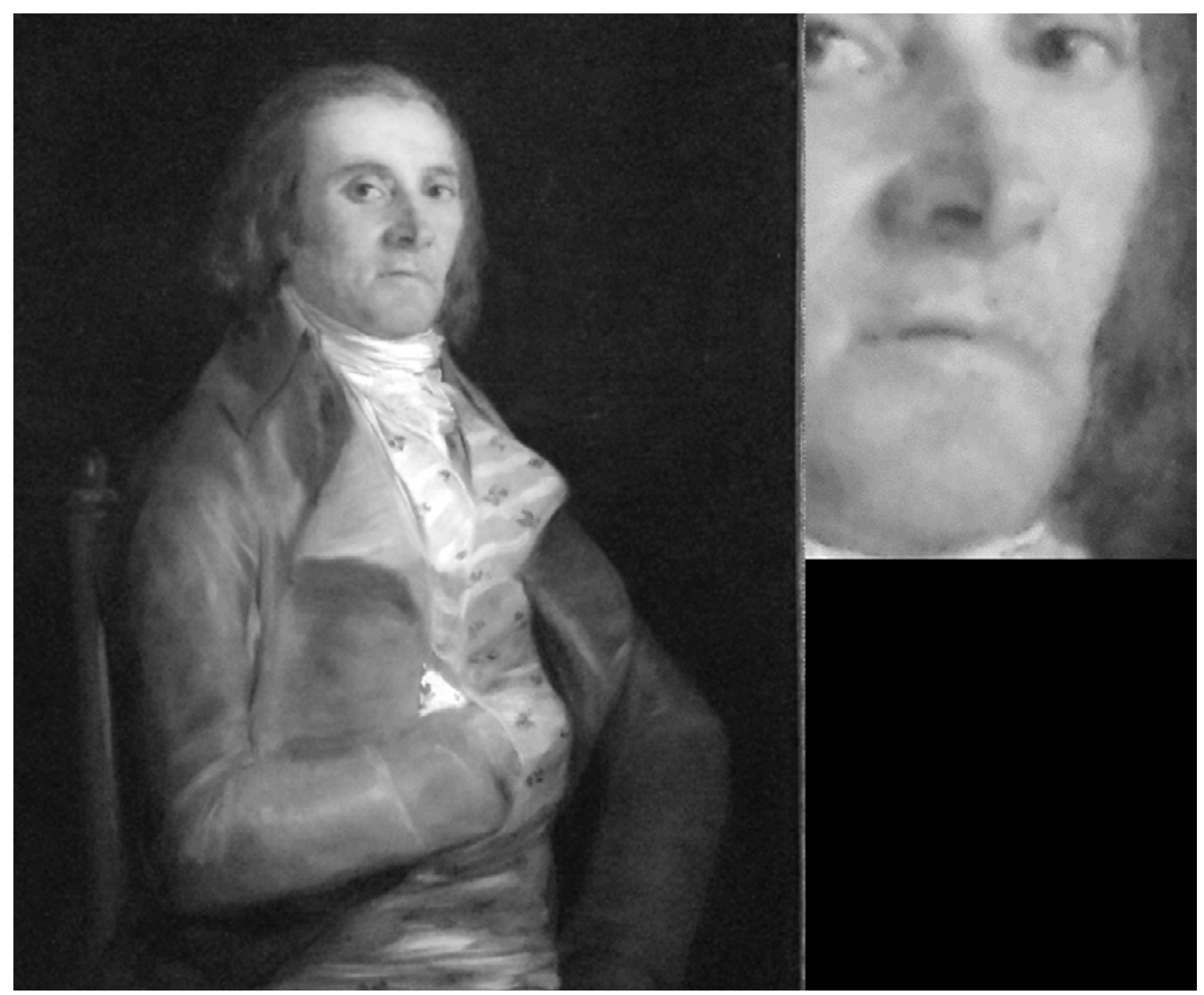


su tratamiento se hace habitualmente a base de antivíricos (aciclovir 0 derivados) y/0 corticoides ${ }^{6,7}$.

Pero, ¿qué nos dice el retrato de Goya de la personalidad del retratado? Sin duda, fue persona sagaz para los negocios, pues obtendría buenos réditos de la venta de su colección de arte y logró importantes puestos cortesanos. ¿Cómo era su temperamento? ¿Era de carácter taciturno, como su amigo Goya tras su sordera, o bien la parálisis facial, con la deformidad que imprimió a su rostro, le llevó a un cambio de carácter? En una profesión y ambiente en que el aspecto exterior eran muy importantes tal defecto debió ocasionarle importantes sufrimientos, siquiera psicológicos.

De ellos nada sabemos, aunque por analogía con una experiencia personal, pueda intuir yo algo de los mismos. Un hombre de la edad aproximada del retratado, y con temperamento muy jovial, unos 7 años antes de su muerte (con 57 años) sufrió intensamente al comprobar cómo cada vez que hablaba o reía se le deformaba la boca en un rictus desagradable, con frecuente incontinencia de saliva. Fue llevado a consulta del más reputado especialista de Neurología en su ciudad, pero el tratamiento no produjo mejoría y las secuelas fueron evidentes hasta el final. Sin embargo, se rehízo y con estoicismo admirable conservó hasta su prematuro término un envidiable sentido del humor. Yo estaba a mediados de mi carrera de Medicina cuando sucedió y pude observar su evolución hasta los primeros años de mi Residencia. Aquel hombre era mi padre.

A Ludivino ("Manolo") Montes Muriel, in memoriam

\section{Bibliografía}

1. ArteHistoria. Francisco de Goya y Lucientes. Andrés del Peral. http: //www. artehistoria. com/v2/obras/1764. htm. [consultado, 19/12/2016].

2. Francisco de Goya. D. Andrés del Peral. https: //www. nationalgallery. org. uk/paintings/francisco-de-goya-don-andres-del-peral [consultado, 19/12/2016]. (Rótulo: Observacion personal).

3. Glenddining N. Goya. La década de los Caprichos. Retratos 1792-1804. Madrid: Real Academia de Bellas Artes de San Fernando 1992. pp. 113-311.

4. Luna JJ. Goya. 250 aniversario. Madrid: Museo del Prado, 1996. pp. 369-70.

5. Morales y Asín JL. Goya. Catálogo de la pintura. Madrid: Editorial Alpuerto, 1994. p. 246

6. Gronseth GS, Paduga R. Evidence-based guideline update: steroids and antivirals for Bell palsy: report of the Guideline Development Subcommittee of the American Academy of Neurology. Neurology. 2012; 79: 2209-13.

7. Eviston TJ, Croxson GR, Kennedy PGE, Hadlock T, Krishnan AV. Bell's Palsy: Aetiology, clinical features and multidisciplinary care. J Neurol Neurosurg Psych. 2015; 86: 1356-61.

Julio Montes Santiago

Medicina Interna. Complejo Hospitalario Universitario. Vigo. 